\title{
The influence of interactive, non-interactive, implicit and explicit CSR communication on young adults' perception of UK supermarkets' corporate brand image and reputation
}

\author{
Authors: Britt Denise Lauritsen and Keith J. Perks \\ University of Brighton, Brighton Business School
}

\begin{abstract}
Purpose - Corporations communicate CSR policies through a variety of methods, and the goal of the study is to explore young adult consumers' communication preferences and the implications for managers to effectively communicate CSR to boost their corporate brand image and reputation.
\end{abstract}

Design/methodology/approach - Set within the context of the UK supermarket industry, the study adopts a qualitative research approach and a purposeful sampling method, collecting data from thirty young adult consumers in the South East of the UK. The data collection method used was online bulletin board focus groups, face-to-face focus groups, face-to-face interviews, and an online questionnaire. Research propositions are developed, evaluated and synthesized into a conceptual framework.

Findings - The findings show that interactive CSR communication functions as an effective method of improving consumers' emotional brand value, knowledge and memory of supermarket CSR. The findings have the potential to induce a more positive perception by young adults of supermarket CSR corporate brand image and reputation.

Research and practical implications - The implications for theory development are in the under-researched area of interactive CSR communication. The research provides practical strategic recommendations regarding effective communications to help guide managers in their planning and execution of their CSR endeavours.

Originality/value - The research provides new empirical insights into theory and knowledge of interactive CSR communication and how supermarkets can communicate CSR in a manner, which is appealing and engaging for young adult consumers, therefore more likely to strengthen their perception of a supermarket corporate brand image and reputation.

Keywords: CSR Communication, Supermarket CSR Consumer Interactivity, Young Adult Perceptions, Corporate Brand Image and Reputation.

Paper type: Research paper 


\section{Introduction}

Corporations face stakeholder scrutiny, pressure and expectations to be socially responsible (Aguilera et al., 2007; Du et al., 2010; Simmons, 2009), and if they do not fulfil their social contract (Brown and Deegan, 1998), risk threats of stakeholder criticism, particularly from consumers who are increasingly aware of their social and environmental consumption footprint (White et al., 2012). As a consequence, the significance of a corporation's capability to demonstrate and legitimize its social and environmental credentials cannot be underestimated. This is manifested in the many corporations that now embed CSR in their corporate positioning and marketing DNA (Campbell, 2007; Pirsch et al., 2007; Schmeltz, 2012) as an instrument to strengthen their corporate brand image and reputation. As CSR policies help consumers evaluate and distinguish individual brands (Wang and Anderson, 2011), the degree to which consumers are aware of a corporation's CSR communication endeavours plays a pivotal role in how this translates into corporate benefits (Andreu et al., 2011; Green and Peloza, 2011). Nevertheless, the CSR field is lacking research in CSR communication (Beckmann et al., 2006; Reisch, 2006; Du et al., 2010), particularly insights into consumers' discernment of CSR communication (Podnar, 2008; Bigné et al., 2012; Öberseder et al., 2013).

Extant research has explored the effectiveness of non-interactive implicit (Morsing et al., 2008), and explicit communication (Schmeltz, 2012) strategies and content to improve CSR image and reputation. Corporations use implicit non-interactive CSR communication such as annual and social reports (Patten, 1991) to fulfil the needs of what is expected by society (Matten and Moon, 2008), as they are reluctant to explicitly advertise their CSR actions due to possible stakeholder scepticism of social responsibility claims from a biased self-serving source (Schroder, 1997; Perks, et al., 2013). However, despite the risk of stakeholder scepticism, corporations are willing to adopt explicit non-interactive advertising media and 
explicit interactive media to build a strong CSR image due to the ineffectiveness of CSR reports to reach a wider audience (Pomering and Dolnicar, 2009; Fieseler et al., 2010). Given increasing ethical interest from consumers, managers need to know more about how their corporate brand image and reputation is affected by consumer interactivity in CSR communication, particularly in an era where online media enables transparent interaction between consumers and organizations (Robinson et al., 2012; Schmeltz, 2012).

\section{Scope and goal of the study}

Firstly, our study focuses on supermarkets as they are part of the daily lives of consumers (Jones et al., 2005), interacting regularly on and off-line, and hence likely to be under frequent scrutiny by customers. Secondly, we selected young adults' perceptions of CSR communication as a frame of reference as they are regarded as a yardstick for socio-cultural changes (Kruger and Mostert, 2012), educated, critical and demanding consumers (Grant, 2004) manifesting high levels of social consciousness and care for social causes (Hyllegard et al., 2011).

As corporations communicate CSR policies through a variety of interactive/non interactive, explicit and implicit communication, the goal of our study is to explore and evaluate young adult consumers' knowledge and perceptions of UK supermarkets and the implications for managers to effectively communicate CSR to boost their corporate brand image and reputation.

\section{Development of the propositions}

Supermarket corporate brand image and reputation

Corporate reputation is the sum of individual stakeholder experiences and perceptions of 
corporate identity and image (Barnett, et al., 2006) and a measure of the relative esteem in which an organization is held, based on its CSR record and how a firm responds to events. As supermarkets stock a wide range of their own private label brands (Martenson, 2007), consumers are more likely to perceive these businesses as corporate brands in any evaluation of supermarket brand image and reputation.

\section{CSR and ethical consumerism}

Ethical consumerism is evolving into an integral part of modern life whereby ecological, ethical and social concerns are becoming a social norm influencing consumer attitudes (Seyfang, 2006; Megicks et al., 2008; Trudel and Cotte, 2009). Evidence of the emergence of ethical consumerism was found in a survey in which $41 \%$ of respondents had a strong sense of personal responsibility in dealing with climate change and do everything they can to live ethically (Guardian Sustainable Business, 2011). This movement in social attitudes adds a further dimension to the pressure on corporations, as consumers are not only ethically concerned about corporations' environmental and social impact, but also with their personal consumption behaviour (Du et al., 2010). However, despite these concerns consumers do not always reward socially responsible or ethical brands in their purchasing behaviour (Carrigan and Attalla, 2001; Bray et al., 2011). Hence, while the ethical change in consumer attitudes amplifies the pressure on companies to be more socially responsible in their behaviour, it does not necessarily translate into economic rent from consumers' willingness to purchase ethical brands or products.

Research findings on consumer attitudes towards CSR and their consumption response are inconclusive with some finding a relationship (e.g. Brown and Dacin, 1997; Lee and Shin, 2010) and others none (e.g. Sen and Bhattacharya, 2001; Luo and Bhattacharya, 2006; Luchs 
et al., 2010). One explanation for these mixed findings may be that while ethical consumers demonstrate increased interest in supporting CSR-active organizations, they have also become more conversant with corporate marketing techniques (Du et al., 2007; Vanhamme and Grobben, 2009). Consequently, consumers are aware of the value that CSR can add to corporations (Bhattacharya and Sen, 2004), and therefore more alert to the ulterior motives for ethical and socially responsible strategies and activities (Webb and Mohr, 1998; Porter and Kramer, 2004; Luo and Bhattacharya, 2006). When consumers sense self-interest as the motive for CSR, it creates consumer scepticism towards the ethical and social responsibility claims of organizations (Forehand and Grier, 2003; Ellen et al., 2006; Jahdi and Acikdilli, 2009; Pomering and Johnson, 2009b). However, while consumer scepticism towards CSR efforts can shape corporate reputation (Pomering and Johnson, 2009a; Du et al., 2010), and impact on a consumer's decision to reward or not reward CSR-active firms (Becker-Olsen et al., 2006), scepticism is an instinctive consumer coping mechanism to deal with the persuasive powers of corporate advertising and branding (Darke and Chaiken, 2005; Obermiller et al., 2005). Nonetheless as a result of consumers' advanced understanding of CSR, they acknowledge that CSR practices can yield intrinsic and extrinsic corporate value (Ellen et al., 2006; Sen et al., 2006: White et al., 2012), and are more resilient to negative news about CSR-active organizations (Luo and Bhattacharya, 2006). Therefore, consumers understand CSR is in a corporation's self-interest but also realise that such activities benefit society and the planet (Du et al., 2010) thus we suggest the following proposition:

P1: Consumers understand and accept that CSR initiatives benefit a corporation's selfinterest, society and the planet. 


\section{The CSR communication dilemma}

Consumers have become more critical of organizations' CSR corporate communication strategies, influencing how they make brand choices (Fan, 2005), forcing marketers to evaluate their use of CSR as an image and reputation management tool (Bigné et al., 2012). However, due to an inadequate appreciation of how consumers understand and perceive CSR (Megicks et al., 2008; Podnar, 2008; Bigné et al., 2012; Öberseder et al., 2013), guidelines on how to communicate CSR to consumers remain unclear (Beckmann et al., 2006; Reisch, 2006; Pomering and Johnson, 2009a; Du et al., 2010). Research is inconclusive as to which type of communication method most effectively informs consumers about CSR initiatives. Some argue that implicit communication methods, through corporate reports and websites, are the most effective, as explicit communication increase the likelihood consumers sense corporate self-interest as the core motive for communicating CSR (Morsing et al., 2008). Others contend that explicit communication methods are more effective, as consumers rely on CSR communication to assess and contrast different brand morals (Schmeltz, 2012; Wang and Anderson, 2011), and expect to be openly informed about negative and positive corporate behaviour (Pomering and Dolnicar, 2009). However, in the era of the internet, web 2.0 and social media, the implicit/explicit and the private/public domains blur, allowing for interactivity and open debate among consumers (Mangold and Fauld, 2009), which corporations need to participate in (Downey and Fenton, 2003).

Further, the majority of consumers rarely actively seek information on corporations' socially responsible activities (Stoll, 2002), regardless of their proclaimed interest in receiving more CSR information. Morsing and Schultz (2006, p.325), propose that CSR communication normally falls into three categories; the 'stakeholder information strategy', the 'stakeholder response strategy', or the 'stakeholder involvement strategy'. The first two are one-way and 
two-way asymmetrical communication strategies. The 'stakeholder involvement strategy' takes into account stakeholder opinions when determining CSR activities, representing an emerging approach of interactive CSR communication which is a two-way symmetrical communication process. In this approach, CSR issues are recognized, prioritized and acted upon in collaboration with consumers (Fieseler et al., 2010), whereby the corporate brand evolves into a 'negotiated brand' (Gregory, 2007, p.62). Moreover, corporations projecting a genuine interest in co-creation and customer dialogue improve relationships with customers (Prahalad and Ramaswamy, 2000; Payne et al., 2008; Simmons, 2009). Therefore, interactive CSR communication could cultivate a more dedicated and satisfied consumer audience (Morsing and Schultz, 2006). Thus we propose:

P2: While consumers do not actively seek information about CSR, they prefer corporations to be explicit and engaging in their communication about their CSR activities through interaction and involvement strategies.

\section{Affective CSR brand value through interaction}

Irrespective of time and place, consumers can create viral heat waves on both good and bad corporate behaviour through off and online social sharing and interaction, either making or breaking a brand image and reputation (Fieseler et al., 2010; Campbell et al., 2011). However, while research attention has been directed at the economic effects that consumer interaction has on corporations, there is less focus on how interaction influences consumers' psychological responses (Bendapudi and Leone, 2003) in terms of their affective experience and relationship with brands (Pomering and Johnson, 2009b) and customer satisfaction (Wa Chan et al., 2010). Being supportive of and taking part in CSR initiatives and actions adds personal and emotional value to the individual (Du et al., 2007; Green and Peloza, 2011), 
such as overall wellbeing (Bhattacharya and Sen, 2004); personal satisfaction in terms of 'self-definition', 'self-enhancement', 'self-distinctiveness' (Hildebrand et al., 2011, p.1358), and emotional altruistic value associated with contributing to the welfare of the planet and society (Strahlevitz and Myers, 1998; Robinson et al., 2012).

Interactive CSR initiatives can be communicated offline as well as online and although many organizations project their CSR commitment through websites with the potential for consumer interaction (Nielsen and Thomsen, 2007; Sweeney and Coughlan, 2008), the majority fail to enable and encourage consumer engagement (Lewis, 2003; Fieseler et al., 2010). Instead, involving consumers in two-way interactive CSR dialogue will enable organizations to create emotional stimuli (Schmeltz, 2012). Thus we propose:

P3: Consumers will perceive interactive CSR communication more appealing than noninteractive CSR communication, as interaction is more likely to act as an emotional stimuli and offer self-enhancement value.

\section{Consumer knowledge, awareness and perceptions of CSR branding}

Although the employment of CSR strategies and activities yield reputational and economic value (e.g. Du et al., 2007; Hildebrand et al., 2011), the extent to which these objectives are realised is contingent on consumers' knowledge, awareness and perception of organizations' CSR initiatives and communication (Andreu et al., 2011; Green and Peloza, 2011) which determines corporate brand image and reputation so understanding these dimensions is necessary (Cornelissen, 2004; Fan, 2005). However, with consumers possessing limited recall and recognition of CSR activities (Auger et al., 2003; Bhattacharya and Sen, 2004; Pomering and Dolnicar, 2009), they have a poor foundation for incorporating CSR attributes into their 
corporate brand image and reputation evaluation (Andreu et al., 2011).

Extensive exposure to CSR communication has been found to increase consumers' memory and knowledge of CSR activities, and improves the chances of this functioning as a heuristic in their CSR perception formation and brand image and reputation assessment (Maignan, 2001). Using two-way symmetrical consumer-brand dialogue through highly noticeable, transparent and accessible media channels, interactive CSR communication could improve consumer memory, knowledge and perceptions of a brand's CSR activities (Hinz et al., 2011). We thus propose:

P4: Interactive CSR communication will positively influence consumers' knowledge, memory, and perception of a supermarket's CSR activities.

\section{Methodology}

The research aim is to probe and explain how consumers perceive and respond to supermarket CSR branding, to develop knowledge and understanding of how organizations can foster more effective CSR communication strategies. Our research seeks to assess whether interactive, as opposed to non-interactive, implicit and explicit CSR communication would be more effective in enhancing supermarket corporate brand image and reputation, based on four propositions developed from the literature. These were explored in a qualitative study of supermarket consumers adopting an iterative approach in which modified or new propositions may emerge from the data analysis (Hogan et al., 2014). The use of qualitative research methodology was deemed appropriate given the research aim to explore, explain and understand consumers' underlying thoughts about CSR communication about sensitive issues 
such as ethical consumerism (Brigley, 1995). From this, the research develops new insights for supermarkets to improve their corporate brand image and reputation (Eckstein, 1992).

\section{Sample and sampling method}

The sample consisted of thirty young adult (aged 20-35) consumers who live in the Southeast of the UK of which $60 \%$ were female and $40 \%$ were male with a mean respondent age of 28 . With the average age group being 28 , the sample was mainly in the higher age category and respondents had to be contributing towards their household grocery shopping and regularly shop at one or more of the supermarkets in the study.

Recruitment and selection of respondents was carried out through online snowball and personal intercept purposeful sampling. The online presence (Facebook) established contact with difficult-to-reach respondents and enabled us to recruit a geographically broader sample (Aaker et al., 2007). Respondents gave their consent prior to their inclusion in the study and were then sent screening questions to ensure they fulfilled the specific sample requirements (Kent, 2007).

\section{Questionnaire design and data collection methods}

As the study aim was to explore, in-depth, consumers' perceptions of supermarket CSR initiatives and the effectiveness of different communication methods in improving corporate brand image and reputation, we developed a set of semi-structured questions to allow for probing and exploration. The researchers posed the same questions in one-on-one and group research settings as well as in the offline and online research contexts respectively, so that we were able to analyse, compare data and evaluate the propositions across the different data collection methods. 
Four multiple data collection methods were employed in the study, allowing for triangulation thereby increasing the credibility of our findings (Burke Johnson et al., 2007). The four data collection methods were: online bulletin board focus groups, face-to-face focus groups, faceto-face interviews and an online questionnaire. For the online bulletin board focus group, a closed communication forum was created on the social media platform, Facebook, where 5-6 questions were posted everyday over a period of three days. Respondents were asked to spend 10-15 minutes daily answering the questions, reading remarks from other respondents and to comment on these wherever appropriate. The online bulletin board focus group was chosen as a communication method of young adults in their daily interactions (Schmeltz, 2012). Further, unlike traditional focus groups, the online bulletin board gave participants the opportunity to reflect on the research topic and questions over several days (Malhotra, 2010; Chenail, 2011). The final data collection method was a self-completion online questionnaire, which six respondents received via e-mail. Iterative adjustments were made to the semistructured research questions and exercises as the research progressed (Remington and Tyler, 1979).

The research exercises included respondent rating of five CSR communication channels; unaided recall of general supermarket CSR initiatives; aided recall of specific supermarket CSR campaigns and initiatives; and recognition of the same specific supermarket CSR campaigns and initiatives. Respondents' aided recall was explored by outlining the name of the supermarkets' long-term CSR campaigns and a prominent 2012 CSR initiative. Respondents were then asked to identify which supermarket campaigns they thought the initiatives belonged to. Following this exercise, respondents were presented with pictures of the CSR campaigns and initiatives and asked to indicate which of them they recognized. 


\section{Analytical method}

Descriptive coding (Richards, 2009) was initially completed by allocating an identity (ID) to each respondent, indicating which study they took part in, the supermarket they usually visit, and their personal details. We then applied topic coding (Gibson and Brown, 2009; Richards, 2009), wherein the data was arranged and labelled according to different themes and subthemes. The data analysis contained two types of coding: a priori coding for themes that were determined before the data examination, and a posteriori coding for themes that emerged from the data (Gibson and Brown, 2009).

Following the a priori and a posteriori data coding, inductive thematic analysis (Seale, 2004; Gibson and Brown, 2009) was applied. On completion of the thematic analysis, a content analysis using both text and a numeric count of replications (Marshall and Rossman, 2011) was carried out in order to indicate the degree of supporting evidence for each proposition to add rigour, and to address some of the concerns and criticism that qualitative data analysis is prone to anecdotalism (Silverman, 2005; Bryman and Bell, 2011). The thematic assessments comprised of both inter (micro-analysis of individual respondent data) and intra analyses (macro-analysis across all respondent data). Table I demonstrates how the numeric replication count analysis scheme was applied.

\section{INSERT TABLE I HERE}

\section{Findings}

In the findings each of the four propositions was evaluated and discussed with the use of evidence from the analysis. 
P1: Consumers understand and accept that CSR initiatives benefit a corporation's selfinterest, society and the planet.

There was very strong evidence that respondents believe supermarkets' involvement in CSR is motivated by self-interest to improve their reputation, staying ahead of competitors, and bottom-line profits (Yoon et al., 2006; Pirsch et al., 2007). Despite respondents' awareness of the benefits, which corporations accrue from their CSR activities, only three expressed strong sceptical attitudes:

They [supermarkets] have to make it look like they are doing us a favour, so we think they are good, whereas they are probably trying to screw us any way they can.

These three respondents were also very negative towards advertising, suggesting this could influence their attitudes towards CSR practices and communication (Drumwright, 1996; Mögele and Tropp, 2010). There was very strong supporting evidence that other respondents were tolerant of corporate self-interest and acknowledged that supermarkets reap extrinsic and intrinsic benefits from their CSR endeavours, such as increased profits and reputation, if they are able to combine such motives with acting ethically and contributing to society and the environment (Ellen et al., 2006; Sen et al., 2006; Du et al., 2010):

I think it's better that supermarkets are successful because of socially responsible initiatives rather than using immoral promotions and exploitation of vulnerable people... so yes, and of course it's a win-win situation. We're always going to need to do our grocery shopping in supermarkets like these... so if they combine corporate matters with social actions I can't see why anyone would think that's bad for society or 
themselves?

While extant research finds that consumers question corporate motives for engaging in CSR (Porter and Kramer, 2004; Lou and Bhattacharya, 2006), our evidence questions the view that consumers are sceptical towards CSR (e.g. Ellen et al., 2006; Morsing and Schultz, 2006; Pomering and Johnson, 2009b). Thus our first proposition has credibility.

P2: While consumers do not actively seek information about CSR, they prefer corporations to be explicit and engaging in their communication about their CSR activities through interaction and involvement strategies.

There was strong evidence that respondents support the use of explicit communication channels such as TV and radio, online, magazines or newspapers, advertisements inside and outside of supermarket stores and product labelling:

[A]dvertising is obviously the one that works the best for the charity or cause so maybe we should really all prefer explicit advertising because it helps the most, instead of thinking in-store because it would bother you less...

There was very strong supporting evidence that respondents generally prefer to be actively informed about supermarket CSR, and the few who seemed to be less interested were those expressing sceptical views towards advertising. We found moderate supporting evidence that respondents are equally interested in being informed about socially responsible and irresponsible supermarket behaviour (Pomering and Dolnicar, 2009), and currently use supermarket CSR as a key influence in their supermarket choice. There was similarly 
moderate supporting evidence that respondents who currently do not consider supermarket CSR in their choice of supermarket would do so if they possessed more knowledge about the supermarkets' CSR practices (Lee and Shin, 2010; Wang and Anderson, 2011). These respondents felt they had insufficient knowledge about supermarkets' CSR activities to distinguish between their individual CSR initiatives and thereby use CSR as a determinant of supermarket choice:

A supermarket is a place where I put a lot of money, and if their CSR commitments became more visible I would take it more into consideration [when choosing where to shop].

It has no bearing on where I shop, as I wouldn't know which supermarket puts the most emphasis on this and which supermarket supports the most worthwhile causes.

There was very strong supporting evidence that respondents perceive supermarket CSR as insufficiently communicated and want to learn more about supermarket CSR through explicit CSR communication, but they do not intend to actively seek this information. Finally, we found very strong supporting evidence suggesting that respondents prefer supermarkets to be explicit in their CSR communication using interactive rather than non-interactive methods; thus giving credence to proposition 2 .

P3: Consumers will perceive interactive CSR communication more appealing than noninteractive CSR communication, as interaction is more likely to act as an emotional stimuli and offer self-enhancement value. 
The majority of respondents perceive CSR as either very valuable or somewhat valuable to themselves (e.g. Du et al., 2007; Green and Peloza, 2011):

My personal life - very valuable! I love feeling that I am a better person because of my choices of consumption.

It affects your conscience if you are aware of what they are trying to achieve and it feels good to support and in some cases help - even if it is indirectly by shopping. So it does affect where I shop but so does convenience.

Additionally, the findings revealed very strong evidence that respondents perceive interactive CSR communication as attractive and appealing to them. They emphasized how it would make them feel more influential and valued in a supermarket's CSR decision-making, rather than feeling ignored through the practice of one-way communication. By opening up the opportunity for consumers to participate in supermarkets' CSR activities, interactive CSR communication thus contributes to their feeling of self-enhancement (Hildebrand et al., 2011), and belief that supermarkets engage in CSR out of genuine concern for society and not simply for self-serving interests (Sen et al., 2006: White et al., 2012):

It would be attractive [interactive CSR], as I get a chance to say which activities supermarkets should be engaged in, instead of the supermarkets choosing the activities for their own convenience. I will feel that the supermarket cares for my opinion too, and really cares for the society. I will feel more involved in a way. Maybe then, I will care more about what the supermarkets do and where I then shop.

It would be more positive, as I would feel that I'm contributing. 
Even though I know they [supermarkets] still benefit from CSR, I would see it as more favourable to know that my voice is heard because then at least they are also respecting what their customers want, and not just their own interests.

While respondents indicate CSR-supportiveness adds personal emotional attributes, they also believe interaction with supermarkets on CSR issues provides a stronger foundation on which to stimulate a sense of gaining emotional value (e.g. Robinson et al., 2012). Thus, proposition three has credence.

Nevertheless, there was strong supporting evidence respondents wanted proof that their CSR participation is acted upon; the more supermarkets can demonstrate consumer opinions have been taken into consideration, the more positive they will be towards the supermarkets' CSR commitment and corporate brand image and reputation. Moderate supporting evidence suggests that if respondents discover their consumer involvement is not being acted upon, it could provoke a negative perception of the supermarket's CSR corporate brand image and reputation.

I would think it was great - if it was easy to do. I think CSR would be more interesting and become a more concrete topic for consumers. I think my images of the different supermarkets would be better and CSR activities would maybe be more credible than now if consumers' participation really was acted upon.

Well yes, definitely. If consumers' opinions are actually respected and acted upon then it would definitely seem more genuine. I guess it would be more "socially responsible". 
If they can prove that my vote makes a difference then I would think better of supermarket CSR. Not that I think bad of it now, but like, I would think their claims of who and how and what they help would be more credible. But if it turns out that my votes were useless then it would just backfire. And yeah, then my perception of that supermarket would just decrease.

The respondents emphasized that they would feel betrayed and their negative feelings would have a larger influence on the supermarket's corporate brand image and reputation than the positive feelings they held towards the brand prior to its use of interactive CSR communication (Ariely, 2009). Based on this insight, we developed a new proposition:

New Proposition 3b: While consumers encourage interactive CSR communication, they expect proof that their engagement is acted upon.

P4: Interactive CSR communication will positively influence consumers' knowledge, memory, and perception of a supermarket's CSR activities.

When exploring respondents' knowledge of supermarket CSR most could recall several general CSR initiatives and were convinced that all of the major supermarkets practice CSR, such as local sourcing and stocking of fair-trade products. However, they struggled to recall specific supermarket CSR initiatives and the associated supermarket, with the majority also having trouble distinguishing between them. Eighteen out of the thirty respondents participated in the aided recall and recognition exercise on the highlighted supermarket campaigns and initiatives. (See table II for the results). 


\section{INSERT TABLE II HERE}

This indicates very strong supporting evidence that respondents lack the ability to recall and recognize even the most prominent CSR initiatives of the year in which the study took place, as well as the overall supermarket CSR campaigns. This supports earlier research evidence that consumers have limited knowledge of CSR activities (e.g. Pomering and Dolnicar, 2009). There was, however, very strong supporting evidence that respondents see interactive communication as a way of increasing their knowledge and memory of supermarket CSR initiatives:

If I actually influenced, or got involved in it [CSR initiative], it would definitely stay in my memory... If I were involved in it I would definitely remember more... You wouldn't get involved in something that you don't know what is, so you would have to get the knowledge about it to know what and how you're influencing it.

It would definitely influence both my knowledge and memory of a CSR campaign if I had made a difference to the outcome.

Further, there was very strong supporting evidence that respondents felt interactive communication would make them feel more recognized (e.g. Prahalad and Ramaswamy, 2000), and stimulate them to pay more attention to supermarkets' CSR activities:

I think it would be attractive... like if you get to pick things it instantly makes it more attractive because you know that you were part of something and you'd be like ' $u h h, I$ helped do that''. 
Well I guess all people like to be able to influence their community and the environment in some way so yeah, definitely, of course it is better to have the opportunity than not having the opportunity.

Together, the findings that interactive CSR communication will be more effective than noninteractive CSR to promote consumers' emotional experience and increase their knowledge and memory of CSR activities, were found to act as driving mechanisms for securing a more positive corporate brand image and reputation (Du et al., 2010; Green and Peloza, 2011), hence lending credence to proposition four. The conceptual framework is based on the findings and presented in figure I below.

\section{INSERT FIGURE 1 HERE}

\section{Conclusions and Discussion}

In our study we found that respondents were aware of the benefits of CSR to supermarkets, themselves, society and the planet, and recognized that while different these need not be conflicting objectives (proposition 1). As such, consumers are aware of the potential societal, personal and corporate benefits of CSR initiatives, and thus less likely to develop negative perceptions of explicit CSR communication through advertising and other media. Secondly, while we found that respondents do not actively seek information about CSR, they prefer supermarkets to be explicit and engaging in communicating their CSR activities through interaction and involvement strategies (proposition 2). Further, respondents perceive interactive CSR communication, which enables effective information exchange, more appealing than non-interactive CSR communication, as interaction is likely to act as an emotional stimuli offering self-enhancement value (proposition 3). Thus supermarkets in 
order to bolster their credibility, corporate brand image and reputation, need to engage their consumers via media that encourage and facilitate interaction and involvement (Morsing and Schultz, 2006). In the analysis of the data we also discovered that while respondents encourage interactive CSR communication, they expect proof that their engagement is acted upon (new proposition 3b) and hence supermarkets should incorporate customer suggestions into their initiatives. Finally, we found CSR communication positively influences respondent knowledge, memory, and perception of CSR initiatives (proposition 4) and supermarkets which promote explicit interactive and involvement CSR communication will increase their customers' self-enhancement value. This in turn will then strengthen the supermarkets' corporate brand image and reputation.

\section{Theoretical contributions and implications}

The research provides insights into consumer awareness and perception of CSR, contributing to knowledge in the relatively scarce body of CSR communication literature (Polonsky and Jevons, 2009). In using the concept of interactive supermarket CSR communication, the study responds to calls for research to evaluate the efficacy of two-way communication on consumer perceptions of corporate brand image and reputation (Robinson et al., 2012). The implication of the finding that explicit and two-way CSR communication is more effective than implicit and one-way CSR communication methods in projecting CSR corporate branding to consumers is pivotal for the development of theory and knowledge in the underresearched area of interactive CSR communication (Schmeltz, 2012). A further implication of the study is that interactive CSR communication strategies will appeal to consumers' altruistic feeling of contributing to society and the environment, and stimulate consumers' sense of self-enhancement (Robinson et al., 2012). 


\section{Managerial contributions and implications}

Since the degree to which CSR commitments translate into corporate benefits is contingent on how well consumers recall and recognize CSR endeavours (Green and Peloza, 2011), the limited respondent knowledge of supermarket CSR should be of concern to managers. The study clarifies that the extent to which consumers are aware of, interested in, and able to remember supermarket CSR initiatives depends not only on the explicitness of CSR communication, but more inherently, on their level of involvement in CSR-decision making. Managers failing to encourage interactive CSR communication offer limited incentives for consumers to feel influential and gain emotional value from a supermarket's corporate brand. Supermarket executives are encouraged to listen and respond to ethically conscious and influential young adult consumers through communication which is open to their suggestions in terms of influencing CSR initiatives and directions. The implications for supermarkets are that engaging consumers in CSR decision-making can protect and enhance their corporate brand image and reputation.

\section{Limitations and future research directions}

Whilst our study has limitations common to qualitative research in terms of its generalizability, the research objective of exploring a relatively under-researched area of interactive CSR communication and its effects on corporate brand image and reputation the choice of a qualitative research methodology was appropriate. The influence of interactive CSR versus non-interactive CSR communication would be an interesting avenue for future research, exploring in particular the degree to which interactive CSR communication has a similar potential influence on corporate brand image and reputation for corporations operating in other sectors, consumer segments and national contexts. 


\section{References}

Aaker, D. A., Kumar, V. and Day, G. S. (2007), Marketing Research, 9th ed., John Wiley and Sons, Inc., USA.

Aguilera R. V., Rupp, D. E., Williams, C. A. and Ganapathi J. (2007), "Putting the s back in corporate social responsibility: a multilevel theory of social change in organizations", Academy of Management Review, Vol. 32 No. 3, pp. 836-863.

Andreu L, Mattila, A. S. and Aldás J. (2011), "Effects of message appeal when communicating CSR initiatives", in Okazaki, S (Ed), Advances in Advertising Research Vol. 2: Breaking New Ground in Theory and Practice, Gabler Verlag, Germany, pp. 261-275.

Auger P., Burke, P. F., Devinney, T. M. and Louviere, J. J. (2003), "What will consumers pay for social product Features?”, Journal of Business Ethics, Vol. 42 No. 3, pp. 281-304.

Ariely, D. (2009) "The end of rational economics", Harvard Business Review, No. JulyAugust, pp. 78-84.

Barnett, M.L., Jermier, J.M. and Lafferty, B.A. (2006), "Corporate reputation: the definitional landscape", Corporate Reputation Review, Vol. 9 No. 1, pp. 26-38.

Becker-Olsen, K.L., Cudmore, B.A. and Hill, R.P. (2006), "The impact of perceived corporate social responsibility on consumer behavior", Journal of Business Research, Vol. 59, No. 1, pp. 46-33.

Beckmann, S. C., Morsing, M. and Reisch, L. (2006), "Strategic CSR communication: an emerging field", in Morsing, M and Beckmann, S. C. (Eds), Strategic CSR Communication, DJØF Publishing, Copenhagen, pp. 11-36.

Bendapudi, N. and Leone, R.P. (2003), "Psychological implications of customer participation in co-production", Journal of Marketing, Vol. 67 No. 1, pp. 14-28.

Bhattacharya, C. B. and Sen, S. (2004), "Doing better at doing good: when, why and how consumers respond to corporate social initiatives", California Management Review, Vol. 47 No. 1, pp. 9-24.

Bigné, E., Currás-Pérez, R. and Aldás-Manzano, J. (2012), "Dual nature of cause-brand fit influence on corporate social responsibility consumer perception", European Journal of Marketing, Vol. 46 No. 3/4, pp. 575-594.

Bray, J., Johns, N. and Kilburn, N. (2011) "An exploratory study into the factors impeding ethical consumption." Journal of Business Ethics, Vol. 98 No. 4, pp. 597-608.

Brigley, S. (1995), "Business ethics in context: researching with case Studies", Journal of Business Ethics, Vol. 14 No, 3, pp. 219-226.

Brown, N. and Deegan, C. (1998), "The public disclosure of environmental performance information-A dual test of media agency setting theory and legitimacy theory", Accounting and Business Research, Vol. 29 No. 1, pp. 21-42. 
Brown, T. J. and Dacin, P. A. (1997), "The company and the product: corporate associations and consumer product responses", Journal of Marketing, Vol. 61 No. 1, pp. 68- 84.

Bryman, A. and Bell, E. (2011), Business Research Methods, 3rd ed., Oxford University Press, New York.

Burke Johnson, R., Onwuegbuzie, A.J. and Turner, L.A. (2007). Toward a definition of mixed methods research, Journal of Mixed Methods Research, Vol. 1 No. 2, pp. 112-133.

Campbell, J. L. (2007), "Why would corporations behave in socially responsible ways? Institutional theory of corporate social responsibility", Academy of Management Review, Vol. 32 No. 3, pp. 946-967.

Campbell, C., Pitt, L. F., Parent, M. and Berthon, P. R. (2011), "Understanding consumer conversations around ads in a WEB 2.0 World", Journal of Advertising, Vol. 40 No. 1, pp. 87-102.

Carrigan, M. and Attalla, A. (2001). "The myth of the ethical consumer - do ethics matter in purchase behaviour?", Journal of Consumer Marketing, Vol. 18 No.7, pp.560 - 578.

Chenail, R. J. (2011), "Qualitative researchers in the blogosphere: using blogs as diaries and data", The Qualitative Report, Vol. 16 No. 1, pp. 249-354.

Cornelissen, J. (2004). Corporate Communications: Theory and Practice, Sage Publications: London.

Darke, P. R. and Chaiken, S. (2005), "The pursuit of self-interest: self-interest bias in attitude judgment and persuasion", Journal of Personality and Social Psychology, Vol. 89 No. 6, pp. 864-83.

Downey, J. and Fenton, N. (2003), "New media counter publicity and the public sphere", New Media \& Society, Vol. 5 No. 2, pp. 185-202.

Drumwright, M. E. (1996), "Company advertising with a social dimension: the role of noneconomic criteria", Journal of Marketing, Vol. 60 No. 4, pp. 71-87.

Du, S., Bhattacharya, C. B. and Sen, S. (2007), "Reaping relationship rewards from corporate social responsibility: the role of competitive positioning", International Journal of Research in Marketing, Vol. 24 No. 3, pp. 224-241.

Du, S., Bhattacharya, C. B. and Sen, S. (2010), "Maximizing business returns to corporate social responsibility (CSR): the role of CSR communication", International Journal of Management Reviews, Vol. 12 No. 1, pp. 9-18.

Ellen, P., Webb, D. and Mohr, L. (2006), "Building corporate associations: consumer attributions for corporate socially responsible programs", Journal of the Academy of Marketing Science, Vol. 34 No. 2, pp. 147-57.

Eckstein, H. (1992), Regarding Politics: Essays on Political Theory, Stability and Change, University of California Press: Berkeley. 
Fan, Y. (2005), "Ethical branding and corporate reputation", Corporate Communications: An International Journal, Vol. 10 No. 4, pp. 341-350.

Fieseler, C., Fleck, M. and Meckel, M. (2010), "Corporate social responsibility in the blogosphere", Journal of Business Ethics, Vol. 91, pp. 599-614.

Forehand, M. R. and Grier, S. (2003), "When is honesty the best policy? The effect of stated company intent on consumer skepticism", Journal of Consumer Psychology, Vol. 13 No. 3, pp. 349-356.

Gibson, W. J. and Brown, A. (2009), Working With Qualitative Data, Sage Publications Ltd., London.

Grant, I.C. (2004). "Communication with young people through the eyes of marketing practitioners", Journal of Marketing Management, Vol. 20, pp. 591-606.

Green, T. and Peloza, J. (2011), "How does corporate social responsibility create value for consumers?", Journal of Consumer Marketing, Vol. 28 No.1, pp. 48-56.

Gregory, A. (2007), "Involving stakeholders in corporate brands: the communication dimension", Journal of Marketing Management, Vol. 23 No. 1/2, pp. 57-73.

Guardian Sustainable Business: Sustainable Living Hub. (2011). "What motivates consumers to make ethically conscious decisions?" available at http://www.theguardian.com/sustainablebusiness/motivates-consumers-environmental-ethical-decisions, (accessed 28 April 2014).

Hildebrand, D., S. Sen and Bhattacharya, C. B. (2011), "Corporate social responsibility: a corporate marketing perspective", European Journal of Marketing, Vol. 45 No. 9/10, pp. $1353-1364$.

Hinz, O., Skiera, B., Barrot, C. and Becker, J. U. (2011), "Seeding strategies for viral marketing: an empirical comparison", Journal of Marketing, Vol. 75 No. 6, pp. 55-71.

Hogan, S. P., Perks, K.J. and Russell-Bennett, R. (2014), "Identifying the key sociocultural influences on drinking behavior in high and moderate binge-drinking countries and the public policy implications", Journal of Public Policy \& Marketing, Vol. 33 No.1, pp. 93-107.

Hyllegard, K.H., Yan, R.N., Ogle, J.P., and Attman,J. (2011). "The influence of gender, social cause, charitable support, and message appeal on gen Y's responses to cause-related marketing”, Journal of Marketing Management, Vol. 27, pp. 100-123.

Jahdi, K. and Acikdilli, G. (2009), "Marketing communications and corporate social responsibility (CSR): marriage of convenience or shotgun wedding", Journal of Business Ethics, Vol. 88 No. 1, pp. 103-113.

Jones, P., Comfort, D., Hillier, D. and Eastwood, I. (2005), "Corporate social responsibility: a case study of the UK's leading food retailers”, British Food Journal, Vol. 107 No. 6, pp. 423435 . 
Kent, R. (2007), Marketing Research: Approached, Methods and Applications in Europe, Thomson Learning, London.

Kruger, L., and Mostert, P.G. (2012). "Young adults' relationship intentions towards their cell phone network operators", South African Journal of Business Management, Vol. 43 No. 2, pp. 41-49.

Lee, K. H. and Shin, D. (2010), "Consumers' responses to CSR activities: the linkage between increased awareness and purchase intention", Public Relations Review, Vol. 36 No. 2, pp. 193-195.

Lewis, S. (2003), "Reputation and corporate responsibility", Journal of Communication Management, Vol. 7 No. 4, pp. 356-364.

Luchs, M. G., Naylor, R. W., Irwin, J. R. and Raghunathan, R. (2010), "The sustainability liability: potential negative effects of ethicality on product preference", Journal of Marketing, Vol. 74 No. 5, pp. 18-31.

Luo, X. and Bhattacharya, C. B. (2006), "Corporate social responsibility, customer satisfaction, and market value", Journal of Marketing, Vol. 70 No. 4, pp. 1-18.

Maignan, I. (2001), "Consumers' perceptions of corporate social responsibilities: a crosscultural comparison”, Journal of Business Ethics, Vol. 30 No. 1, pp. 57-72.

Malhotra, N. K. (2010), Marketing Research: An Applied Orientation, 6th ed., Pearson Education, Inc., New Jersey.

Mangold, W.G. and Faulds, D.J. (2009), "Social media: The new hybrid element of the promotion mix", Business Horizons, Vol. 52 No. 4, pp.357-365.

Marshall, C. and Rossman, G. B. (2011), Designing Qualitative Research, 5th ed., Sage Publications Ltd., London.

Martenson, R. (2007) "Corporate brand image, satisfaction and store loyalty: a study of the store as a brand, store brands and manufacturer brands", International Journal of Retail \& Distribution Management, Vol. 35 No. 7, pp. 544-555.

Matten, D. and Moon, J. (2008). "Implicit" and "explicit" CSR: a conceptual framework for a comparative understanding of corporate social responsibility", Academy of Management Review, Vol. 33 No. 2, pp.404-424.

Megicks, P., Memery, J. and Williams, J. (2008), "Influences on ethical and socially responsible shopping: evidence from the UK grocery sector", Journal of Marketing Management, Vol. 24 No. 5-6, pp. 637-659.

Mögele, B. and Tropp, J. (2010), "The emergence of CSR as an advertising topic: a longitudinal study of German CSR advertisements", Journal of Marketing Communications, Vol. 16 No. 3, pp. 163-181. 
Morsing, M. and Schultz, M. (2006), "Corporate social responsibility communication: stakeholder information, response and involvement strategies", Business Ethics: A European Review, Vol. 15 No. 4, pp. 323-338.

Morsing, M., Schultz, M. and Nielsen, K. U. (2008), "The "Catch 22" of communicating CSR: findings from a Danish study", Journal of Marketing Communications, Vol. 14 No. 2, pp. 92-111.

Nielsen, A. E. and Thomsen, C. (2007), "Reporting CSR - what and how to say it?", Corporate Communications: An International Journal, Vol. 12 No. 1, pp. 25-40.

Obermiller, C. Spangenberg, E. and MacLachlan, D. L. (2005), "Ad scepticism", Journal of Advertising, Vol. 34 No. 3, pp. 7-17.

Öberseder, M., Schlegelmilch, B. B. and Murphy, P. E. (2013), "CSR practices and consumer perceptions”, Journal of Business Research, Vol. 66 No. 10, pp. 1839-1851.

Patten, D. M. (1991), "Exposure, legitimacy, and social disclosure", Journal of Accounting and Public Policy, Vol. 10 No. 4, pp. 297-308.

Payne, A. F., Storbacka, K. and Frow, P. (2008), "Managing the co-creation of value", Journal of the Academy of Marketing Science, Vol. 36 No. 1, pp. 83-96.

Perks, K.J., Farache, F., Shukla, P. and Berry, A.J. (2013). Communicating responsibilitypracticing irresponsibility: CSR advertisements through the lens of legitimacy theory and impression management, Journal of Business Research, Vol. 66 No. 10, pp. 1881-1888.

Pirsch, J., Gupta, S. and Grau, S. L. (2007), “A framework for understanding corporate social responsibility programs as a continuum: an exploratory study", Journal of Business Ethics, Vol. 70 No. 2, pp. 125-140.

Podnar, K. (2008), "Guest editorial: communicating corporate social responsibility”, Journal of Marketing Communications, Vol. 14 No. 2, pp. 75-81.

Polonsky, M. and C. Jevons, C. (2009), "Global Branding and Strategic CSR: An Overview of Three Types of Complexity”, International Marketing Review, Vol. 26 No.3, pp. 327-47.

Pomering, A. and Dolnicar, S. (2009), "Assessing the prerequisite of successful CSR implementation: are consumers aware of CSR initiatives?", Journal of Business Ethics, Vol. 85 No. 2, pp. 285-301.

Pomering, A. and Johnson, L. W. (2009a), "Constructing a corporate social responsibility reputation using corporate image advertising", Australasian Marketing Journal, Vol. 17 No. 2, pp.106-114.

Pomering, A. and Johnson, L. W. (2009b), "Advertising corporate social responsibility initiatives to communicate corporate image: inhibiting scepticism to enhance persuasion", Corporate Communications: An International Journal, Vol. 14 No. 4, pp. 420-439. 
Porter, M. E. and Kramer, M. R. (2004), "Strategy and Society: The link between competitive advantage and corporate social responsibility", Harvard Business Review, Vol. 84 No. 12, pp. $5-12$.

Prahalad, C. K. and Ramaswamy, V. (2000), "Co-opting customer competence", Harvard Business Review, Vol. 78 No. 1, pp. 79-87.

Reisch, L. (2006), "Communicating CSR to Consumers: An Empirical Study". In Morsing, M. and Beckmann, S. C. (Eds), Strategic CSR Communication, DJØF Publishing, Copenhagen, pp. 185-211.

Remington, M. and Tyler, P. (1979), "The social functioning schedule - a brief semistructured interview", Social Psychiatry, Vol. 14, pp. 151-157.

Richards, L. (2009), Handling Qualitative Data: A Practical Guide, 2nd ed., Sage Publications Ltd., London.

Robinson, R.S., Irmak, C and Jayachandran, S. (2012), "Choice of cause in cause-related marketing", Journal of Marketing, Vol. 76 No. 4, pp. 126-139.

Schmeltz, L. (2012), "Consumer-orientated CSR communication: focusing on ability or morality?", Corporate Communications: An International Journal, Vol. 17 No. 1, pp. 29-49.

Schroder, K.C. (1997), "Cynicism and ambiguity: British corporate responsibility advertisements in the 1990's", in Nava, M. Blake, A. and B. Richards, B. (Eds), Buy This Book Studies in Advertising and Consumption, Routledge, London, pp. 276-290.

Seale, C. (2004), Researching Society and Culture, 2nd ed., Sage Publications Ltd., London.

Sen, S., Bhattacharya, C. B. and Korschun, D. (2006), "The role of corporate social responsibility in strengthening multiple stakeholder relationships: a field experiment", Journal of the Academy of Marketing Science, Vol. 34 No. 2, pp. 158-166.

Sen, S. and Bhattacharya, C. B. (2001), "Does doing good always lead to doing better? Consumer reactions to corporate social responsibility", Journal of Marketing Research, Vol. 38 No. 2, pp. 225-243.

Seyfang, G. (2006), "Ecological citizenship and sustainable consumption: examining local organic food networks", Journal of Rural Studies, Vol. 22 No. 4, pp. 383-395.

Silverman, D. (2005), Doing Qualitative Research: A Practical Handbook, 2nd ed., Sage Publications Ltd., London.

Simmons, J. A. (2009), "Both sides now: aligning external and internal branding for a socially responsible era”, Marketing Intelligence \& Planning, Vol. 27 No. 5, pp. 681-697.

Stoll, M. L. (2002), "The ethics of marketing good corporate conduct", Journal of Business Ethics, Vol. 41 No. 2, pp. 121-129. 
Strahilevitz, M., and Myers, J. (1998), "Donations to cause as purchase intentions: How well they work may depend on what you are trying to sell", Journal of Consumer Research, Vol. 24 No. 4, pp. 434-446.

Sweeney, L. and Coughlan, J. (2008), "Do different industries report corporate social responsibility differently? An investigation through the lens of stakeholder theory", Journal of Marketing Communications, Vol. 14 No. 2, pp. 113-124.

Trudel, R. and Cotte, J. (2009), "Does it pay to be good?", Sloan Management Review, Vol. 50 No. 2, pp.61-68.

Vanhamme, J. and Grobben, B. (2009), "Too good to be true!: the effectiveness of CSR history in countering negative publicity", Journal of Business Ethics, Vol. 85 (April), pp. $273-283$.

Wa Chan, K., Yim (Bennett) C. K. and Lam, S.S.K. (2010), "Is customer participation in value creation a double-edged sword? Evidence from professional financial services across cultures", Journal of Marketing, Vol. 74 No. 3, pp. 48-64.

Wang, A. and Anderson, R. B. (2011), "A multi-staged model of consumer responses to CSR communication", Journal of Corporate Citizenship, Vol. 41 March, pp. 51-68.

Webb, D. and Mohr, L. (1998), "A typology of consumer responses to cause-related marketing; from skeptics to socially concerned", Journal of Public Policy \& Marketing, Vol. 17 No. 2, pp. 226-38.

White, K., MacDonnell, R. and Ellard, J. H. (2012), "Belief in a just world: consumer intentions and behaviors toward ethical products", Journal of Marketing, Vol. 76 No. 1, pp. 103-118.

Yoon, Y., Gürhan-Canli, Z. and Schwarz, N. (2006), "The Effect of Corporate Social Responsibility (CSR) Activities on Companies With Bad Reputations", Journal of Consumer Psychology, Vol.16 No. 4, pp. 377-390. 
Table I: Numeric replication count analysis scheme

\begin{tabular}{|c|c|}
\hline \multicolumn{2}{|c|}{ COUNTS OF RESPONDENT OPINIONS } \\
\hline $\begin{array}{c}\text { DEGREE OF } \\
\text { SUPPORTING EVIDENCE }\end{array}$ & $\begin{array}{c}\text { NUMBER OF SUPPORTING } \\
\text { PARTICIPANTS }\end{array}$ \\
\hline Limited & $0-5$ \\
\hline Moderate & $6-12$ \\
\hline Strong & $13-20$ \\
\hline Very Strong & $21-30$ \\
\hline
\end{tabular}

Table II: Recall and recognition exercise results

\begin{tabular}{|c|c|c|c|c|c|c|c|}
\hline & SAINSBURY's & Tesco & ASDA & MORRISONS & $\begin{array}{l}\text { ThE Co- } \\
\text { OPERATIVE }\end{array}$ & $\begin{array}{l}\text { MARKS AND } \\
\text { SPENCER }\end{array}$ & WAITROSE \\
\hline LONG-TERM CSR CAMPAIGN & "20 by $20 "$ & $\begin{array}{l}\text { "Community } \\
\text { Promises" }\end{array}$ & $\begin{array}{c}\text { "Sustainability } \\
360 "\end{array}$ & $\begin{array}{c}\text { "Today: } \\
\text { Taking Good } \\
\text { Care for } \\
\text { Tomorrow" }\end{array}$ & $\begin{array}{l}\text { "Ethical Plan - } \\
\text { Join the } \\
\text { Revolution" }\end{array}$ & "Plan A" & $\begin{array}{l}\text { "The Waitrose } \\
\text { Way" }\end{array}$ \\
\hline & 4 & 2 & 1 & 2 & 5 & 3 & 9 \\
\hline MAJOR CSR ACTIVITY OF 2012 & $\begin{array}{l}\text { Paralympic } \\
\text { Games } \\
\text { Sponsor }\end{array}$ & $\begin{array}{l}\text { Charity of the } \\
\text { Year: Cancer } \\
\text { Research UK }\end{array}$ & $\begin{array}{c}\text { Charity of the } \\
\text { Year: Tickled } \\
\text { Pink } \\
\text { Campaign }\end{array}$ & $\begin{array}{l}\text { Great Taste } \\
\text { Less Waste } \\
\text { Initiative }\end{array}$ & $\begin{array}{l}\text { Join the Green } \\
\text { Schools' } \\
\text { Revolution } \\
\text { Initiative } \\
\end{array}$ & $\begin{array}{c}\text { Oxfam } \\
\text { Schwopping, } \\
\text { Scheme } \\
\text { Initiative } \\
\end{array}$ & $\begin{array}{l}\text { Community } \\
\text { Matters } \\
\text { Initiative }\end{array}$ \\
\hline & 12 & 3 & 1 & 1 & 6 & 1 & 7 \\
\hline TOTAL RECALL FREQUENCY & 16 & 5 & 2 & 3 & 11 & 4 & 16 \\
\hline $\begin{array}{l}\text { TOTAL NUMBER OF RESPONDENTS } \\
\text { WHO RECALLED EITHER THE CSR } \\
\text { CAMPAIGN OR INITIATIVE OR BOTH }\end{array}$ & 12 & 4 & 2 & 2 & 10 & 4 & 11 \\
\hline
\end{tabular}


Figure I: Conceptual framework

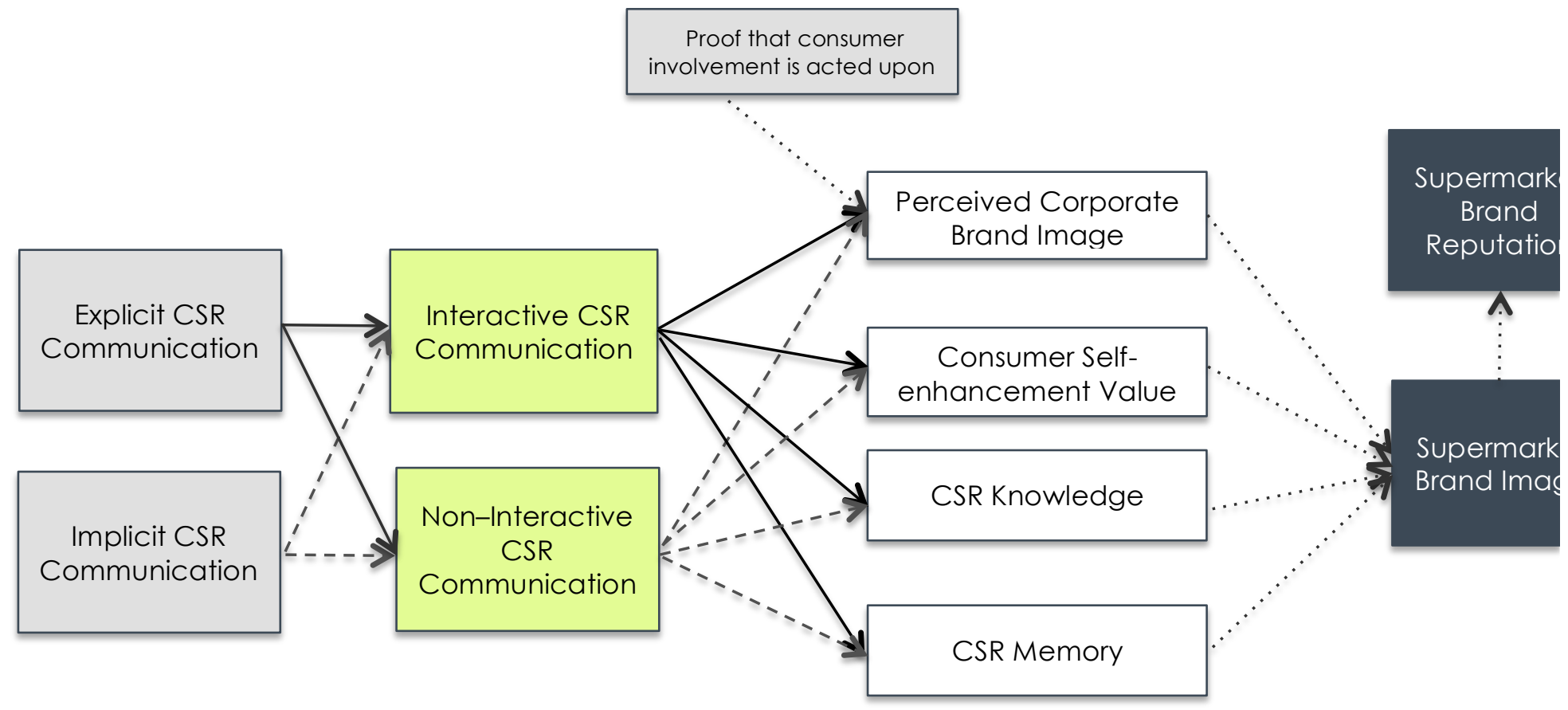

